May 27, 2011

SDN/11/12

\title{
The Too-Important-to-Fail Conundrum: Impossible to Ignore and Difficult to Resolve
}

İnci Ötker-Robe, Aditya Narain, Anna llyina, and Jay Surti

with Alberto Buffa di Perrero, Julian Chow, Marc Dobler, Silvia lorgova, Turgut Kisinbay, Michael Moore, Jiri Podpiera, Katharine Seal, Volodymyr Tulin, and Jianping Zhou 


\title{
INTERNATIONAL MONETARY FUND
}

\author{
Monetary and Capital Markets Department \\ The Too-Important-to-Fail Conundrum: \\ Impossible to Ignore and Difficult to Resolve ${ }^{1}$
}

Prepared by İnci Ötker-Robe, Aditya Narain, Anna Ilyina, and Jay Surti

with Alberto Buffa di Perrero, Julian Chow, Marc Dobler, Silvia Iorgova, Turgut Kisinbay, Mike Moore, Jiri Podpiera, Katharine Seal, Volodymyr Tulin, and Jianping Zhou

Authorized for distribution by José Viñals

May 27, 2011

\begin{abstract}
DISCLAIMER: This Staff Discussion Note represents the views of the authors and does not necessarily represent IMF views or IMF policy. The views expressed herein should be attributed to the authors and not to the IMF, its Executive Board, or its management. Staff Discussion Notes are published to elicit comments and to further debate.
\end{abstract}

JEL Classification Numbers: F33, G18, G20, G21, G28, G32, G33, G38, H12

Keywords: $\quad$ Financial crises, financial stability, too big to fail, too important to fail, moral hazard, resolution, financial regulation, bank capital, contingent capital, bail-in, supervision

Author’s E-mail Address: $\quad$ iotker@imf.org, anarain@imf.org, ailyina@imf.org, jsurti@imf.org

\footnotetext{
${ }^{1}$ We are grateful for the guidance provided by José Viñals and Jonathan Fiechter, and for the very useful input and comments from numerous internal and external reviewers, including during an informal discussion at the IMF Executive Board. The views expressed in this paper are those of the authors. Ivan Guerra and Sofiya Avramova provided excellent research assistance.
} 


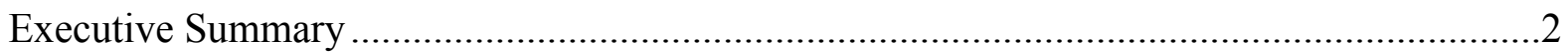

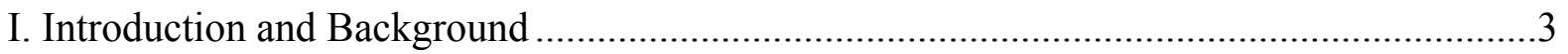

II. The TITF Problem and Some Stylized Facts ................................................................5

III. Will the Current Policy Proposals Resolve the TITF Problem? .....................................

A. How Should the TITF Problem be Addressed? ................................................ 10

B. Structural Measures to Address the TITF Problem................................................... 11

C. Measures to Reduce the Probability and Impact of Failures..................................13

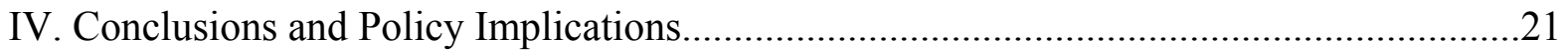

Figures

1. U.S. Financial Institutions: Bigger Borrows Cheaper .............................................6

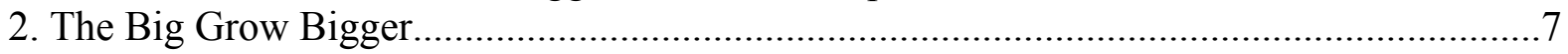

3. Frequency of Distress for Different Types of Institutions ............................................

4. Likelihood of Official Support, Given Distress, for Different Types of Institutions ............9

5. Dealing with the Risks Posed by Systemically Important Financial Institutions Beyond Basel III .................................................................................................. 10

6. Distribution of Banks by Business Model and Scale of Cross-border Activities ...............25

7. Number of Banks in the Top Quartiles of the Distributions by Absolute Size,

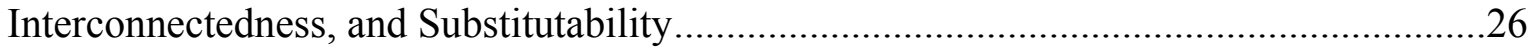

8. Distribution of Banks by Size and Interconnectedness Quartiles, and by Business Model and Region.

Box

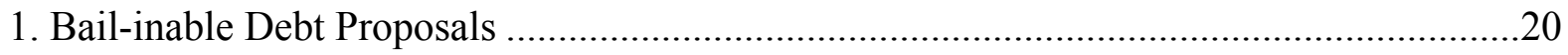

Appendixes

I. Is Big Beautiful? Evidence on the Economies of Scale/Scope and Diversification Benefits of Financial Conglomerates .....................................................................23

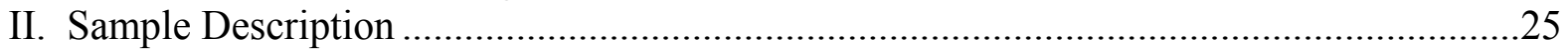

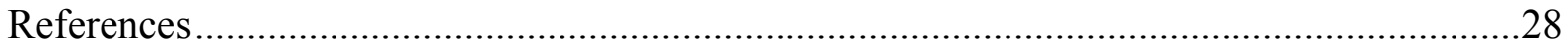




\section{EXECUTIVE SUMMARY}

The unprecedented scope and intensity of the recent financial crisis underscored the tooimportant-to-fail (TITF) problem associated with systemically important financial institutions (SIFIs). Ahead of the crisis, implicit government backing permitted these institutions to take on greater risks without being adequately subject to market discipline and to enjoy a competitive advantage over systemically less important institutions. And when the crisis broke, their scale, complexity, and interconnectedness, which had made them difficult to manage and supervise, also proved too significant to permit them to fail.

Yet, some SIFIs have already become bigger and even more complex following the crisis, and risky lending practices have begun to reappear. The restructuring following the crisis increased the level of concentration in many advanced economies' financial systems, with implications for stability and competitiveness. Policies are therefore needed to make financial institution failures less likely and less devastating when they occur, reestablish market discipline, level the playing field, and spare governments and taxpayers the costs of future bailouts.

The elements of an adequate policy framework to deal with the TITF problem should contain (i) more stringent capital (and possibly liquidity) requirements to limit contribution to systemic risk; (ii) intensive supervision consistent with the complexity and riskiness of SIFIs; (iii) enhanced transparency and disclosure requirements to capture emerging risks in the broader financial system; and (iv) effective resolution regimes at the national and global level to make orderly resolution a credible option, with resolution plans and tools that lead creditors to share any losses.

To reinforce these elements and limit the unintended consequences of tightening the grip on SIFIs, additional efforts are necessary. A better policing of the firewalls between regulated and unregulated segments of the financial sector and enhanced disclosure for the shadow banking system should help limit the possibility that systemic risks are simply shifted to entities subject to less monitoring or oversight. Effective cross-border arrangements for supervisory cooperation and information- and burden-sharing between home and host authorities are essential to facilitate resolution of cross-border groups and contain regulatory arbitrage. Realigning management incentives to match those of the banking group attacks the problem at its root, containing incentives for risk taking.

Work is progressing on these building blocks, but implementation could take several years. Putting the problem to rest requires rapid progress in finalizing a number of complex and important issues: (i) the methodology (and scope of application) to identify SIFIs; (ii) the level, composition, and coverage of a capital surcharge; (iii) institutionalizing international standards for intensive supervision of SIFIs and translating them into national practices; and (iv) enhancing disclosure, addressing data gaps, understanding shadow banks, and achieving consensus on cross-border resolution and information- and burden-sharing arrangements.

Credible action is needed in the interim. There is growing pressure at the national level to take immediate action to limit the risk posed by these institutions. Reaching a consensus at the international level will be more difficult, however, if disparate frameworks are locked in at the national level. It is therefore necessary to start by putting in place credible and visible policies during the transition period to a more robust framework to address the TITF problem. Coordinated action could be taken in particular to require SIFIs to hold significantly more loss-absorbing capital combined with enhanced supervision to limit their tendency to accumulate systemic risk. 


\section{INTRODUCTION AND BACKGROUND}

The unprecedented scope and intensity of the global financial crisis have brought to the fore the well-known "moral hazard" problems associated with SIFIs viewed as too important to fail. ${ }^{2}$ Such institutions may provide benefits arising from the diversification and scale of their operations and facilitate cross-border capital flows and allocation of global savings. At the same time, they can propagate distress to the broader financial system because of the scale of their activities, interlinkages with other financial institutions and markets, and essential functions. Moreover, their size, complexity, and interconnectedness make them challenging to manage, supervise, and resolve, and too important to fail or ignore. This importance, in turn, gives them greater influence over the regulatory and legislative process and a competitive advantage over systemically less important institutions.

Moral hazard arises when the failure of a financial institution (bank or nonbank) can threaten the stability of the entire financial system. As institutions grow in size, complexity, and interconnectedness, the market views them as TITF because their failure would potentially have a devastating impact on the system and the economy. Creditors, and not infrequently credit rating agencies, may not price the full credit risk of lending to an institution deemed TITF. Markets provide them with a lower cost of funds than smaller and less complex institutions, and this funding advantage facilitates their further expansion. If they become troubled, governments often provide funds to prevent their failure or guarantees to protect uninsured creditors, validating perceptions of their TITF status. Because such institutions fail to fully internalize the social costs of their operations, the reduced market discipline allows shareholders and management to take greater risks, leading to inefficient capital allocation, potential liabilities for taxpayers, and a competitive advantage over systemically less important institutions.

The nature of the TITF problem has become more profound with the growing interconnectedness of national financial systems. Preceding the global crisis, the vast majority of cross-border finance was intermediated by a relatively small number of large, complex financial institutions with extensive cross-border operations. A lack of transparency and limited disclosure of the types and locations of their risk portfolios made it difficult to assess their exposure and potential spillovers. Once the crisis erupted, the interconnectedness of these SIFIs facilitated global propagation of the shocks.

Regulation, supervision, and resolution frameworks and bank risk-management systems did not keep up with these changes. Regulations did not reflect the growing systemic risks posed by such institutions. In many large, complex institutions, risk-management and information technology systems failed to keep up with the banks' new products and business

\footnotetext{
${ }^{2}$ There is a fair amount of confusion on the various definitions of systemically important financial institutions. The focus here is on institutions whose failure could significantly disrupt the wider financial system and economic activity due to their large size, limited substitutability, high complexity, and systemic interconnectedness. Should credible and orderly resolution mechanisms exist and function effectively, failing institutions would no longer be deemed systemic or TITF. In addition, this paper uses the concept of too important to fail (TITF) as opposed to too big to fail (TBTF) to stress that the systemic importance of financial firms depends not only on their size but also on their interconnectedness, complexity, and lack of substitutability of the essential functions they provide.
} 
practices. Supervision was ineffective in identifying the risks generated by new products and slow to address emerging problems. When the institutions became troubled, efforts to resolve them were hampered by their complexity and interconnectedness. The lack of effective and flexible resolution regimes for nonviable institutions, including burden-sharing arrangements between home and host authorities, hindered the resolution process.

The large-scale public support provided during the recent crisis to weak SIFIs prevented their creditors from suffering losses and has magnified the TITF problem. Such extensive support - direct or indirect via guarantees - reinforced perceptions that certain SIFIs, markets, and instruments are too important to fail or ignore. The expectation that such support would be forthcoming strengthened further following the disruptions to global financial systems resulting from the failure of Lehman Brothers. Ironically, the crisis may have contributed to the funding advantage of SIFIs over systemically less important ones. Some of these banks have become even bigger and more complex as a result of the exit of some competitors and through government-assisted mergers and acquisitions among troubled banks.,

\section{If policies are not put into place to discourage the growth and added complexity of SIFIs,} the problem may get worse. Given the potential for failure of an individual firm to cause devastating effects to global financial and economic stability, such failures must be made less likely (prevention) and less devastating when they occur (effective resolution). Addressing this problem is essential to counter the moral hazard that has permitted excessive risk-taking and to curtail the market propensity to underprice the credit and funding risks of SIFIs because of implicit or explicit public support. It will also help level the playing field by reducing the competitive advantage enjoyed by SIFIs over well run but systemically less important institutions. Reducing their complexity and interconnectedness may also make SIFIs easier to manage and thereby facilitate effective supervision. Finally, addressing the TITF problem would reduce the fiscal exposure of governments and taxpayers forced to save SIFIs, the failure of which could threaten fiscal stability (Viñals, 2009).

Various regulatory proposals have been put forward at the national and global level. These seek to (i) curb the ability of financial institutions to become SIFIs by restricting the size, structure, and scope of their activities; (ii) lower the probability of SIFI failures through enhanced regulatory and supervisory requirements that are tighter than the Basel minimum

\footnotetext{
${ }^{3}$ The level of concentration was higher in 2009 than in 2006 in 10 of 14 large advanced economies (Goldstein and Véron, 2010; Alessandri and Haldane, 2009, and Haldane, 2010). The increase in concentration was particularly pronounced during the crisis, with the share of the 10 largest global banks rising from 14 percent in 1999 to 19 percent in 2007 and 26 percent in 2009 (Goldstein and Véron, 2010).

${ }^{4}$ For example, JP Morgan Chase, a combination of several institutions through mergers and acquisitions (Chase Manhattan Bank, JP Morgan \& Co., Bank One, Bear Stearns, and Washington Mutual), now holds more than 10 percent of deposits in the United States. Taken together, JP Morgan Chase, Bank of America (after acquisition of Merrill Lynch), Wells Fargo (after acquisition of Wachovia, the fourth-largest U.S. bank holding company based on assets), and Citigroup issue half of all mortgages and two-thirds of all credit cards, and held 34 percent of all bank deposits in the United States in 2009 (Cho, 2010; and Johnson and Kwak, 2010). The largest U.S. derivatives dealers account for 37 percent of global notional outstanding amount of derivatives, and the 14 largest global derivatives dealers hold 82 percent (Mengle, 2010).
} 
standards; and (iii) reduce the cost and/or impact of SIFI failures by enhancing their resolvability. At the request of the G20, the Financial Stability Board (FSB) and its members proposed a series of policy measures targeted at internalizing the externalities SIFIs impose on the system through stronger supervisory, regulatory, and resolution frameworks, which were endorsed at the November 2010 G20 Summit. Some countries are already moving to implement policies to address some of the risks posed by their SIFIs. ${ }^{5}$

This paper reviews the various policy options for mitigating the risks posed by institutions perceived as TITF and provides current IMF staff views. Section II provides a brief discussion of the TITF problem and some stylized facts on institutions potentially perceived as TITF. Section III discusses the key proposals to address the problem. Section IV concludes and identifies key areas for future work.

\section{The TITF Problem And Some Stylized Facts}

\section{A key risk of SIFIs is that because they are viewed as TITF, markets may permit them to take greater risk, creating moral hazard and posing challenges for policymakers.}

- $\quad$ Although the evidence is mixed, SIFIs may provide diversification benefits across business and/or geographic lines and, up to some threshold, economies of scale (Appendix I). They can provide a safe harbor during times of market distress and absorb other troubled TITF institutions (as occurred during the recent crisis). Globally active institutions facilitate cross-border capital flows and allocate global savings. Some institutions provide unique functions (such as payments, settlements, and clearing) that are essential to the smooth operation of the financial system and the economy.

- $\quad$ Yet, as evidenced by this crisis, SIFIs also have the capacity to spread distress to the broader financial system and economy, given the scale of their activities, the essential functions they provide, and their interlinkages with other financial institutions and markets. The complexity and integrated nature of group structures and operations, with multiple legal entities spanning national borders and business lines, make it very difficult not only to manage and supervise SIFIs but also for orderly resolution in the event of their failure.

- $\quad$ SIFIs also introduce distortions associated with their TITF status:

○ Despite the added risks they pose to financial stability, compared with systemically less important institutions, their implicit or explicit government backing gives them a funding advantage and, therefore, a competitive advantage. Figure 1 shows that

\footnotetext{
${ }^{5}$ Examples include, the United States through the 2010 Dodd-Frank Wall Street Reform and Consumer Protection Act, Switzerland through the measures targeted at its two largest financial institutions, the United Kingdom through the Independent Commission on Banking (IBC) proposals, and the European Union with measures under discussion to facilitate recovery and/or resolution in a crisis and to overhaul the supervisory architecture and crisis management and resolution frameworks.
} 
the largest U.S. banks have been able to borrow funds at lower rates than smaller banks and that this advantage widened after the crisis. ${ }^{6}$

○ Given their size and importance to their domestic economies, these institutions may enjoy strong political ties and hence may be in a position to influence regulatory policies to their advantage.

Figure 1. U.S. Financial Institutions: Bigger Borrows Cheaper
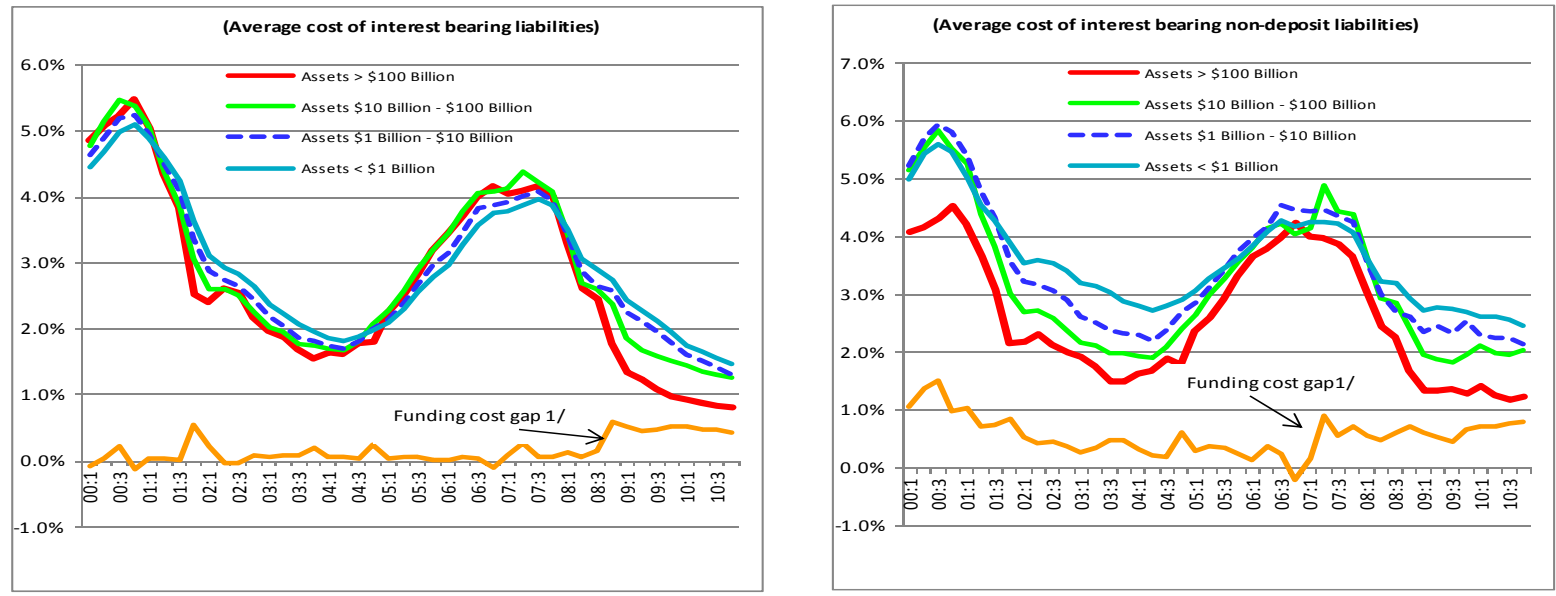

Sources: FDIC; and IMF staff computations.

${ }^{1}$ Funding cost gap between banks with assets of $\$ 10$ to $\$ 100$ billion and banks with assets of more than $\$ 100$ billion.

${ }^{2}$ Interest-bearing nondeposit liabilities include Fed funds purchased, securities sold under agreements to repurchase, Federal Home Loan Bank advances, borrowings from the Federal Reserve's Discount Window, debt securities issued by the reporting institution, interest-bearing liabilities in trading accounts, and other borrowings.

\section{To put the policy proposals to address the TITF problem into a better context, it is useful} to analyze its evolution over time. Over the past decade, the institutions that could be considered as potentially systemic have grown in size. An analysis of a sample of a regionally diverse group of 84 banks that are domiciled in Europe, the western hemisphere, and Asia and are sufficiently large or interconnected to be considered systemic at a national, regional, or global levels shows that their share of assets doubled during 2000-09, reaching about a quarter of the total, and their total assets grew significantly (Figure 2). Their total assets expanded much faster than the rest of the financial system, outpacing in many instances the growth of national economies (notably in Europe). Growth of these banks' balance sheets was driven in part by expansion of their securities portfolios and by mergers and acquisitions. (Appendix II provides the sample details, and Buffa di Perrero and others, 2011, provide further details on these stylized facts.)

\footnotetext{
${ }^{6}$ According to the Federal Deposit Insurance Corporation (FDIC), large U.S. banks with more than $\$ 100$ billion in assets are now borrowing at preferential rates compared with the rest of the industry, especially since the crisis. While differences in financial strength and credit quality may play a role, existence of explicit credit rating criteria for official support suggest that TITF status is also a factor behind the funding cost gap. BIS (2010) reports, for instance, that official support in 2009 for the 50 largest banks translated on average into a three-notch upgrade of their rating, up from a two-notch upgrade in 2006. More recently, the removal in new German legislation of the protection over banks' Tier 2 bonds resulted in a downgrading of several German banks' subordinated Tier 2 debt, on the prospect that the legislation will increase the risk of losses among debt holders in the event of a failure.
} 
Figure 2. The Big Grow Bigger ${ }^{1}$

(In percent)

Distribution of Global Financial Assets by Type of Institution

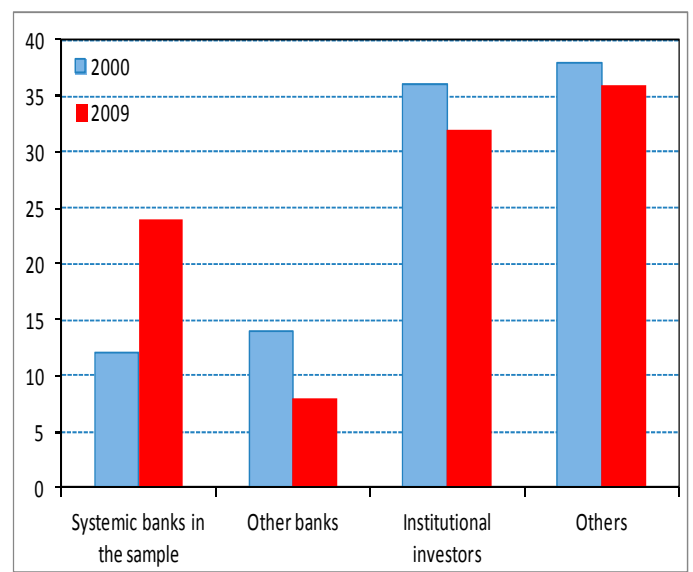

Growth in Assets

(Sample of 84 Banks)

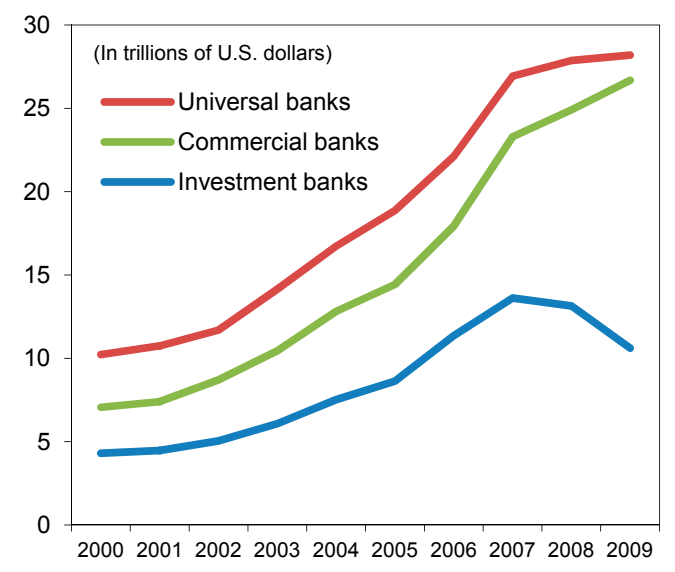

Sources: BankScope; Bloomberg; Bank for International Settlements; Datastream; EMED databases; Economist Intelligence Unit; International Financial Statistics database; IFSL; World Economic Outlook database; Haver Analytics; World Federation of Exchanges; and IMF staff estimates.

${ }^{1}$ Global financial assets are calculated as the total value of equities, bonds, and loans in 46 major advanced and emerging market economies, including all the home countries of institutions in the sample.

\section{Reviewing the evolution and characteristics of the financial institutions in the sample provides some interesting insights: ${ }^{7}$}

- Institutions that can be defined as potential SIFIs (large, highly interconnected, and with limited substitutability) exhibit a variety of characteristics. For example in 2009, an institution in the top quartile of the distribution by size (measured by total assets ranging from $\$ 50$ billion to $\$ 3,000$ billion) was, on average, about five times larger than the average institution in the rest of the sample. There was also a sizable difference in the degree of interconnectedness of those in the top quartile of distribution by interconnectedness versus institutions in the other three quartiles. There is no complete overlap, however, between the largest, the most interconnected, and the least substitutable institutions, suggesting that size alone does not capture all dimensions of the TITF problem (Appendix II).

- Very large and highly interconnected institutions also tend to have significant crossborder activities. This may suggest that policies to address the TITF problem will have

\footnotetext{
${ }^{7}$ The indicators used here to capture systemic importance attempt to replicate, to the extent of data availability and mindful of their limitations, the measures discussed at international forums. Size is measured by (i) total assets of an institution in U.S. dollars and (ii) total assets of an institution as a share of home country nominal GDP. The interconnectedness ranking is approximated by an average of three rankings obtained from publicly available data: (i) securities holdings of an institution in U.S. dollars; (ii) wholesale liabilities in U.S. dollars; and (iii) the wholesale funding ratio. The substitutability ranking is an average of rankings in the league tables for (i) equities, (ii) syndicated loans, and (iii) international bonds. Because it is not possible to construct a good proxy of the complexity of activities/instruments from publicly available data, a complexity ranking is not included.
} 
the greatest effect on institutions that have universal and investment banking focus and that are also highly interconnected with a significant cross-border presence.

- Institutions that were more interconnected appear to have had a higher likelihood of distress during the recent crisis than other financial institutions (Figure 3). The frequency of distress was notably higher for banks with investment and universal banking activities than for commercial banks (likely reflecting, among other things, reliance on more volatile funding sources and balance sheets more sensitive to mark-tomarket accounting). In contrast, the frequency of distress for very large institutions was only marginally higher than for smaller institutions (although the size effect may have been more pronounced if size were measured including off-balance-sheet positions).

Figure 3. Frequency of Distress for Different Types of Institutions (Q1 is the top quartile; Q4 is the bottom quartile; numbers are in percent) ${ }^{1}$
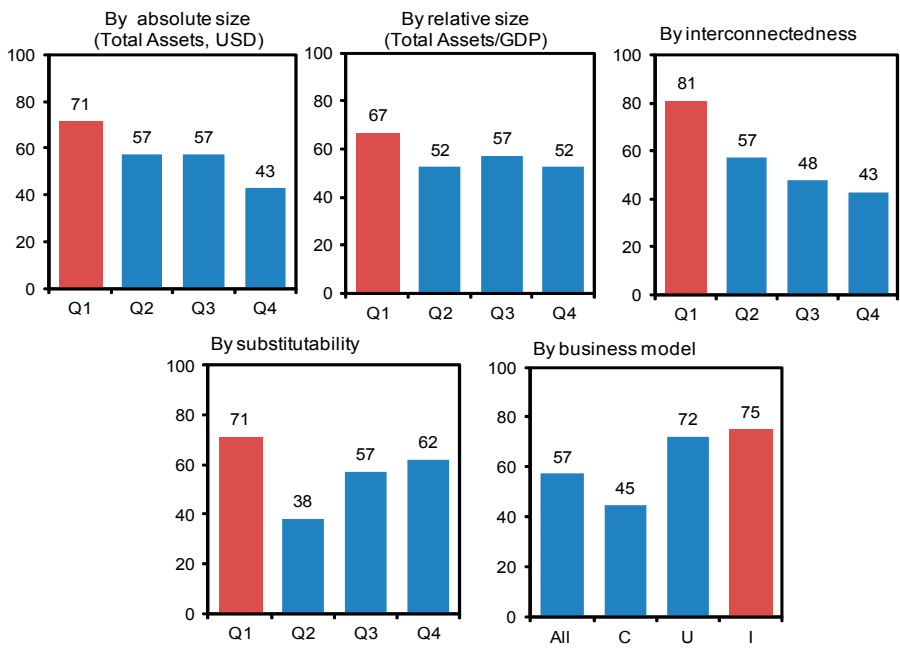

Sources: Bloomberg; BankScope; Banks' reports; World Economic Outlook database; and IMF staff calculations. ${ }^{1}$ Distress frequency refers to the number of distressed institutions as a percent of the total number of institutions in each quartile. "Distress" is defined as a situation when a bank has at least one year of negative return on assets or if it was a recipient of government support during 2007-09 (the period dictated by data availability). While all banks had access to emergency liquidity facilities provided by central banks, the official support here refers to capital injections and asset restructuring.

- $\quad$ The size of an institution relative to its home country GDP or relative to the financial system seems to have played a key role in authorities' decisions about whether to bail it out in the event of distress (Figure 4). During the recent crisis, a retail-oriented bank that was large relative to its home country economy and/or which accounted for a large share of national deposits was more likely to receive official support in the event of distress than other types of banks. Simple logit regression analyses confirm that there is a robust, statistically significant relationship between the probability of official support, given distress, and a distressed bank's size relative to GDP and between the probability of distress and the degree of interconnectedness (Buffa di Perrero and others, 2011).

These stylized facts help explain why policymakers have focused on the size and interconnectedness of SIFIs. Large financial institutions have become larger, and their weight in the global financial system has grown over the past decade. The largest financial institutions 
with universal and investment banking activities are among the most interconnected with global operations. In countries affected by the recent financial crisis, governments protected many of these institutions from failure by providing direct and indirect support to contain the damage on the broader economy (direct support estimated at 6.4 percent of GDP on average in the most crisis-affected countries at end-2010).

Figure 4. Likelihood of Official Support, Given Distress, for Different Types of Institutions (Q1 is the top quartile, Q4 is the bottom quartile, numbers in percent) ${ }^{1}$

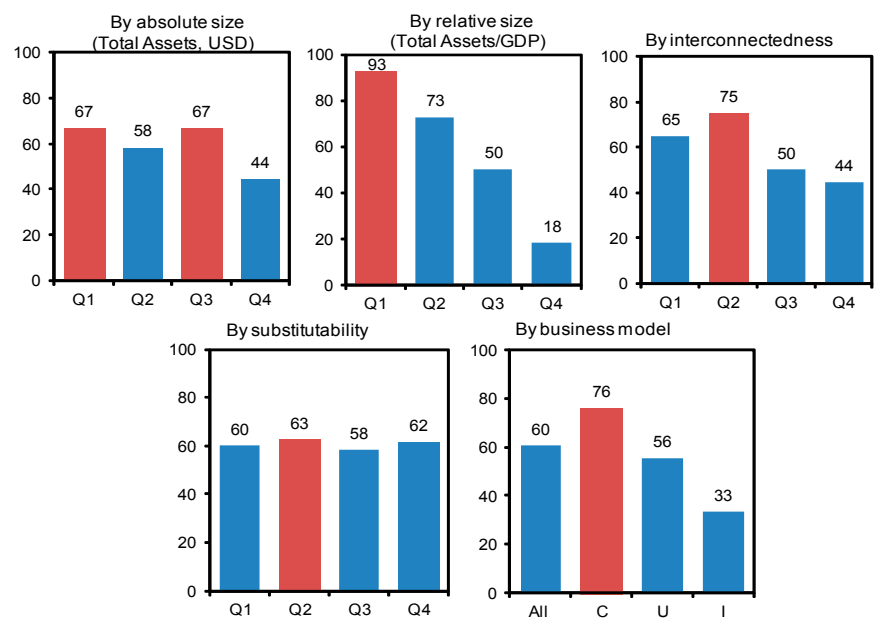

Sources: Bloomberg; BankScope; Banks' reports, World Economic Outlook; and IMF staff calculations.

1 "Likelihood of support given distress" (numbers above the bars in the figure) refers to the share of institutions that received official support as a percent of the total number of institutions that were in distress in each quartile.

\section{Will Current Policy Proposals Resolve the Titf Problem?}

Since the onset of the global financial crisis, significant reforms have been considered at the national and international level to address the major fault lines in the financial system and to safeguard future financial stability. These efforts aim to promote a less leveraged, less risky financial system that supports strong and sustainable economic growth and to prevent a repeat of the errors preceding the recent crisis. The overarching goal is to prevent future financial crises and eliminate or significantly reduce the likelihood that creditors of failing institutions will be bailed out at taxpayer expense.

These initiatives have focused largely on improving existing bank regulations to strengthen capital and liquidity buffers in order to help them better withstand shocks. To make individual banks less likely to fail, the Basel Committee on Bank Supervision (BCBS) adopted a framework with more robust capital buffers consisting of higher and better-quality capital with improved loss absorption, better recognition of counterparty/market risk (for the trading book and complex securitizations), a simple capital-to-asset ratio to limit excessive leverage, tighter liquidity standards for short-term and longer-term funding, and capital buffers over and above the new higher minimum requirements (BCBS, 2009a-c, 2010).

The proposed strengthening of individual institutions' balance sheets, while necessary, will likely be insufficient to prevent future systemic crises. What is needed is a framework that takes into account system-wide interactions among institutions and markets and explicitly addresses externalities and distortions that SIFIs generate. Such a system would attempt to 
reduce excessive risk-taking by SIFIs that are not subject to normal market discipline because of perceptions of implicit or explicit government support in the event of a problem. It would attempt to ensure that no financial institution is considered so systemically important on the basis of its size, complexity, interconnectedness or essential services that it cannot be let to fail.

Policies therefore need to address the double challenge of reducing the likelihood as well as the system-wide implications of a failure. Although there is not yet a consensus on which measures to adopt at the national or global level, much progress has been made in designing a policy framework to identify SIFIs and to reduce the moral hazard risks they pose (FSB, 2010a-f). Figure 5 summarizes the policy options proposed globally and nationally.

Figure 5. Dealing with the Risks Posed by Systemically Important Financial Institutions Beyond Basel III

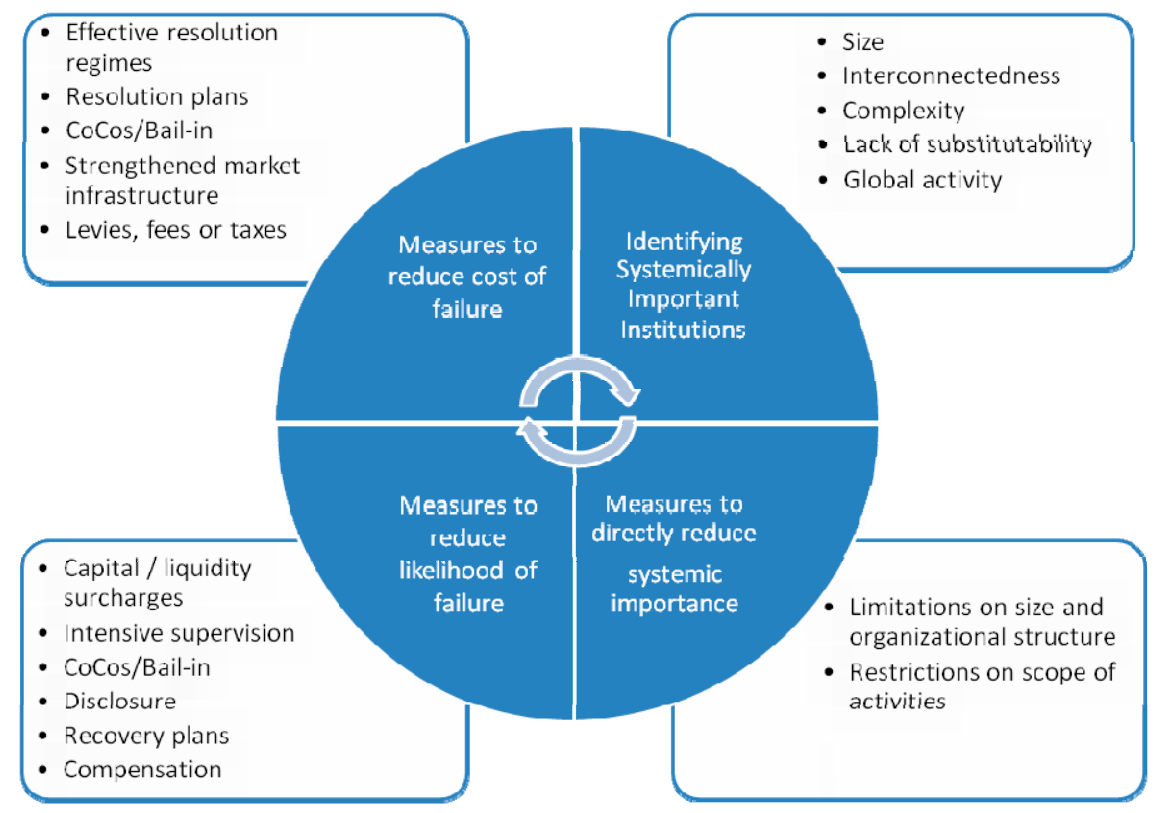

\section{A. How Should the TITF Problem Be Addressed?}

Three complementary approaches may be used to reduce the systemic risks posed by financial institutions viewed as too important to fail: (i) directly reducing the systemic risk of institutions; (ii) reducing the probability of failure of SIFIs; and (iii) constructing a framework to resolve failed financial institutions in a way that minimizes disruption to the financial system when failure occurs. ${ }^{8}$

\footnotetext{
${ }^{8}$ Another important reform measure in the FSB SIFI framework, but not explicitly discussed here, is strengthening the market infrastructure to limit the risks of contagion arising from the interconnectedness of market participants and the limited transparency of counterparty relationships, for example, by clearing over-the-counter (OTC) derivatives through central counterparties and moving standardized OTC contracts to exchange or electronic trading platforms, while ensuring that a critical infrastructure does not itself become a source of systemic risk (FSB, 2010f; and IMF, 2010b).
} 


\section{More specifically, such a framework could include the following components:}

- $\quad$ Structural measures to limit the size and the scope of activities to reduce the likelihood of the institutions being systemically important;

- $\quad$ Carefully designed regulations, including surcharges that reflect an institution's contribution to systemic risk, to encourage it to become less systemically important;

- $\quad$ Enhanced transparency and disclosure to improve market discipline and monitoring;

- Proactive and intensive supervision consistent with the risks an institution poses to the financial system and the complexity of the system;

- $\quad$ An effective resolution framework with tools to enhance resolvability and orderly recovery and wind-down in the event of failure, including developing living wills; and

- $\quad$ Effective burden-sharing with the private sector to internalize losses by creditors and shareholders of failing banks.

The subsequent discussion reviews and assesses these proposals. It argues that the first element — structural measures to limit the size and scope of SIFI activities — while providing a direct way of dealing with the TITF problem, could be difficult to implement and adopt on a globally consistent basis. The remaining set of measures, which are aimed at reducing the likelihood and impact of a failure, could provide a multipronged approach, with mutually reinforcing elements to deal with the TITF problem.

\section{B. Structural Measures to Address the TITF Problem}

\section{Measures to limit the size and scope of activities}

More direct measures to address the TITF problem seek to limit the size, riskiness, or complexity of institutions that make them too big or interconnected to fail. Underlying these measures is the acknowledgment of both the limitations of stronger prudential regulation of SIFIs in preventing crises and in eliminating the negative externalities associated with size, complexity, and interconnectedness, and the constraints on ensuring that resolutions are orderly and nondisruptive. These are reflected in proposals to redesign and refocus the business of financial institutions considered to be TITF (see Chow and Surti, 2011, for a detailed review).

Concrete proposals to limit the size of financial institutions include imposing caps on future growth, selling assets, or breaking up banks into smaller entities. Crisis-related bailouts offered in the EU have been conditional on beneficiary institutions reducing their balance sheets by deleveraging and divesting business units. This approach attempts to address competition issues and reduce the risk that bailouts will exacerbate the moral hazard problem. The Dodd-Frank Act empowers U.S. regulators to cap the size of insured depositories and systemic nonbanks by prohibiting merger applications if the consolidated liabilities of the resulting institution constitute more than 10 percent of the aggregate consolidated liabilities of the whole financial system. 
Proposals to restrict the scope of activities take a variety of different forms. Measures to narrow banking activities include requiring deposit-funded banks to hold low-risk assets and offer payment functions, and requiring private sector lending and investment banking carried out by separate companies funded by nondeposit sources. Measures to separate commercial and investment banking, as under the U.S. Glass-Steagall Act of 1933, include milder forms proposed by the U.K. Independent Banking Commission to ring-fence retail banking businesses from wholesale/investment banking activities through firewalls in a banking group, and the U.S. Volcker Rule that restricts (with exceptions) banks' proprietary trading and investment in, or sponsorship of, hedge and private equity funds. Measures to separate core bank activities from presumably riskier ones are aimed at preventing the destabilization of bank funding and avoiding conflicts of interest arising from bundling services together (for example, making loans conditional on customers purchasing other services). These include the U.S. Swap Pushout Rule that requires certain entities relying on federal assistance and with significant swap business to move such activity to separately capitalized nonbank affiliates.

While direct measures to address the TITF problem have the potential to reduce the likelihood that institutions will generate systemic risk, there are significant challenges in implementation. Opponents argue that the proposals are retrograde and inefficient and could thwart financial innovation and development. Neither size caps nor downsizing banks have gained international support (other than under European Commission (EC) rules related to state aid) and evidence on scale economies is mixed (see Appendix I). While limits on the scope of regulated banks' activities can make them simpler and facilitate identification and management of their risks, potential gains from diversification may be lost. If applied retroactively, the adjustment costs of restructuring integrated business lines could be very high. Differentiating prohibited from permitted activities and enforcing firewalls in a group may also be challenging.

Moreover, requiring banks to shed risky activities may cause such risks to be moved beyond the regulators' reach, though still within the financial system. Pushing the problem elsewhere without addressing its root causes (that is, the incentives for risk taking) may create systemic problems that are difficult to monitor and manage, especially if restrictions on the scope of regulated entities' activities are not accompanied by a wider perimeter of reporting and regulation, and possibly by more intensive supervision of nonbank financial institutions. This also highlights the advantage of more harmonized regulations across borders, which help limit regulatory arbitrage. In principle, riskier activities could be limited through other prudential measures, such as higher risk weights on trading and securitization under Basel, but again, success is predicated on improved governance frameworks and strong supervision.

\section{Measures to simplify the organizational structure of banking groups}

The practical difficulties of achieving global cooperation in crises have led some countries to require greater self-sufficiency of the local operations of foreign banks. Absent effective cross-border information exchange, supervisory coordination, and effective resolution regimes, there has been a natural desire for host authorities to seek to isolate local operations of foreign banks from problems in distressed foreign parents. Many have sought to do this by ensuring that foreign banks operating in their country maintain sufficient capital and liquidity buffers and that there are tight intra-group limits on parent-subsidiary and inter-affiliate operations. 
In light of the recent crisis experience, some authorities believe that such self-sufficiency is best achieved under a subsidiary structure (see Fiechter and others, 2011). In addition to shielding a business from losses elsewhere in the group, the subsidiary structure makes it easier for resolution authorities to spin off individual businesses and affiliates. By comparison, in an integrated branch structure, where the branch is legally inseparable from the parent, it may be difficult for the host country to manage and resolve the branch if the parent fails. Organizing banking groups as a set of separate subsidiaries has also been seen to facilitate implementation of recovery plans (under living wills) by simplifying the legal and financial structure of the group and facilitating the orderly restructuring of various affiliates of a troubled entity.

While resolving cross-border banking groups may, in principle, be less costly in an organizational structure of subsidiaries, imposing self-sufficiency constraints on banking groups, regardless of business models, could be costly for some banks. Imposing a particular organizational structure across the board could eliminate the advantages a given structure provides to a particular business model, while imposing costs on the group's ability to manage risks during normal times. Financial groups organized as subsidiaries may be required to hold higher levels of capital and liquidity than integrated entities. And, while this may be beneficial during times of stress, it limits the ability of the group to shift resources across its operations during normal times. The key to ensuring financial stability, while simultaneously allowing banks to organize themselves in ways that fit best their business models, lies in the design of effective mechanisms to oversee and resolve cross-border banking groups.

\section{Measures to Reduce the Probability and Impact of Failures}

\section{Capital surcharges, liquidity requirements, and fees/levies}

\section{Capital surcharges}

A capital surcharge that reflects the systemic consequences of the failure of an institution is being considered, over and above minimum Basel capital requirements. Such a surcharge would be based on the relative risks posed by a particular institution to the financial system. It would aim to reduce the probability of failure of a SIFI by increasing its capital buffers and loss-absorption capacity beyond the standards imposed on all firms.

If properly calibrated and set high enough, such a surcharge could discourage SIFIs from engaging in activities that increase systemic risk and thus could reduce the probability of such institutions from becoming TITF. In fact, some countries recently adopted or proposed additional capital charges for their SIFIs over the minimum Basel requirement. For example, Switzerland proposed a 19 percent capital-to-risk-weighted asset requirement - with 10 percent common equity Tier 1 - for its two largest banks, and the U.K. IBC proposed a 10 percent common equity Tier 1 ratio for retail banking operations.

Designing and calibrating an appropriate risk-based surcharge, however, has been challenging. Appropriate methodologies are needed to reliably measure and assess both the aggregate risk in the system and the spillover risks via interlinkages. Surcharges could be calibrated to rise gradually as a firm's systemic importance increases. The surcharge could also be adjusted to reflect an institution's potential ease of resolution and thus, at least conceptually, 
be used to create incentives for institutions to organize themselves in ways that facilitate resolution. The challenge will be to avoid designing an overly complicated formula for calculating institutions' capital requirement and to assess the likely consequences of materially higher capital requirements on banks' business models, their provision of credit to the economy, and their overall competitiveness. ${ }^{9}$

Further work is under way to define the scope of application and the types of capital instrument eligible to meet the surcharge. The capital instruments eligible to satisfy the surcharge should be predominantly common equity, but some portion might be met by contingent convertible capital (CoCo). Such proposals are under discussion in the BCBS, FSB, and the EU and have attracted interest in other countries (including Canada, the Netherlands, Switzerland, the United Kingdom, and the United States).

In fact, the use of contingent capital is being considered as a tool to reduce the likelihood or cost of failures. Contingent capital could provide an automatic mechanism to increase equity capital and reduce the debt of a financial institution in the event of a predetermined trigger, while the institution is still a going concern. It enables raising equity capital at times when other options are unavailable due to market conditions or are unattractive to shareholders. Depending on the choice of the trigger and conversion rates, contingent capital could be used to increase capital buffers (as prevention tool if triggers are set high enough relative to the point of insolvency), or ensure prompt recapitalization or greater loss-absorbency (as orderly resolution tool when triggers are set at a low level). A credible threat of losses due to conversion and dilution could help limit risk taking by managers, shareholders, and bondholders, thereby enhancing market discipline. (Pazarbasioglu and others, 2011, give further details on the economic rationale and design to enhance effectiveness while limiting adverse consequences.)

\section{Systemic liquidity charges}

Similar to capital requirements, liquidity requirements may limit an institution's ability to engage in risky funding strategies. Prior to the crisis, some firms embraced risky strategies involving high leverage, reliance on short-term wholesale funding, and large maturity mismatches, providing backup lines of credit to entities such as structured investment vehicles so that they could borrow in the commercial paper market. The BCBS recently announced new liquidity standards that are welcome additions to firm-level liquidity risk management and the current set of prudential regulations. These standards may also help address systemic liquidity risk by raising individual liquidity buffers and reducing maturity mismatches (IMF, 2011). By penalizing exposure to other financial institutions they could also reduce the interconnectedness of the financial system and the likelihood of interrelated liquidity losses.

\footnotetext{
${ }^{9}$ IMF (2010b) offers a method to compute a systemic-risk-based capital surcharge commensurate with the negative effects a firm's failure may have on other parts of the system, reflecting systemic interconnectedness. The method includes two options for computing a surcharge: a standardized approach, which groups institutions into risk categories, and another approach tailored to assess the individual institution's contribution to systemic risk, with both methods smoothed to avoid procyclical effects. The approach is to track institutions' portfolios through the credit cycle, estimate each institution's spillover effects after a stress event at each point in the cycle, and compute the surcharge based on "risk bucketing" or as a function of the institution's marginal contribution to systemic risk and its own probability of default.
} 
Nonetheless, the new liquidity requirements are not intended or designed to mitigate systemic liquidity risk - that is, the tendency of financial institutions to collectively underprice liquidity risk in good times with the expectation of liquidity support from central banks in times of stress. Policymakers have not yet been able to put in place a framework to do this. The absence of a robust methodology to measure systemic liquidity risk has undermined efforts to propose a liquidity surcharge. IMF (2011) suggests three potential measures for systemic liquidity risk, ${ }^{10}$ with the objective of developing an actionable macroprudential tool to help mitigate such risk.

\section{Levies and taxes}

Similar to a capital surcharge, a levy (or deposit insurance premium) could be imposed on financial institutions to discourage excessive risk taking and help pay for the cost of resolving banks, thereby reducing the burden on the taxpayer of SIFI failures. The Fund prepared a report at the request of the G20 to examine options for having the financial sector make a fair and substantial contribution to restructuring the banking system (IMF, 2010a). The concept underpinning such levies is that the financial sector be held accountable for the direct fiscal cost of any future support, thereby making failures less likely (to the extent they discourage risky activities or penalize systemic importance), as well as less damaging (by providing funds to finance resolution in the event of a failure). Some countries have implemented bank levies (France, Germany, Hungary, Sweden, and the United Kingdom) and/or imposed risk-based deposit insurance premiums on banks (the United States).

If introduced, levies should be linked to a credible and effective resolution mechanism to avoid the perceptions that institutions paying the levy will not be allowed to fail (IMF/BIS/FSB, 2010). The levies could be used to build a resolution fund or put aside as general revenue. A system of levies would complement, but not be a substitute for, higher capital requirements. A broad scope of application to all SIFIs could reduce the incentives for migration of systemic risk out of banks. Conceptually, the charges and levies could be designed to limit procyclicality as well as reflect systemic risk contribution, so as to contain circumvention of the regulations (IMF/BIS/FSB, 2010).

\section{More intensive and proactive supervision}

An important corollary to the TITF problem is that large, complex, and interconnected institutions have also become too difficult to manage, govern, or supervise. This only exacerbates their propensity to take on excessive risk. The reports of the Senior Supervisors Group $(2008,2010)$, which looked closely at the risk management practices of the 20 largest institutions in major jurisdictions, laments the fact that some boards and management were unwilling or unable to "articulate, measure and adhere to a level of risk acceptable to the firm."

\footnotetext{
${ }^{10}$ These include: (i) developing a market-based indicator of systemic liquidity risk, based on violations of common arbitrage relationships; (ii) designing a methodology_-based on a combination of balance sheet and market data and options pricing concepts for a firm - to calculate the joint probability of simultaneous liquidity shortfalls and the marginal contribution of a financial institution to systemic liquidity risk; and (iii) designing a macro stresstesting model to gauge the effects of an adverse macroeconomic or financial environment on the solvency of multiple institutions and in turn on systemic liquidity risk.
} 
It also contains a telling account of the "inadequate and fragmented infrastructure" in the largest institutions, which "hindered effective risk identification and measurement" and did not allow for consolidating timely data on concentrations and risk exposures. The obstacles to measuring risk and taking mitigating actions are heightened by the difficulty of developing integrated and accurate information systems that produce reports of the risks generated by a group's complex activities over a large number of business lines located in different jurisdictions. Supervisors "remained unconvinced that the firms are undertaking the full scope and depth of needed improvements."

These impediments to good governance require supervisors to be even more vigilant and demanding in their dealings with SIFIs. Prior to the crisis, some supervisory systems failed to identify the buildup of risks and shortcomings in the SIFIs' approaches to risk measurement and identification and to intervene early to reduce the impact of their actions on the financial system. Ambiguous mandates, inadequate resources, and ineffective techniques played a role, including the failure to identify the systemic risk (such as interconnectedness) that these institutions had created.

The Fund has put forth basic components of an effective supervisory framework, which are particularly important for SIFIs (Viñals and others, 2010). The FSB, in consultation with the Fund, has produced recommendations that supervision be appropriately intense and effective in line with the complexity and systemic importance of institutions (FSB, 2010d). In a candid assessment, the report noted that in some cases "supervisors took their cue from the political economic agenda of the day and did not intervene to question lending practices," concluding that "supervisory independence is rendered even more challenging when dealing with SIFIs, who are often in a position to exercise greater influence on supervisory outcomes."

Developing a framework to make supervision more effective and proactive is now a key part of the approach to deal with the moral hazard risk of SIFIs. The level of supervision must be commensurate with the potential destabilization risk that SIFIs pose to their own and to the global financial system. Supervisors must (i) have the mandate, resources, and operational independence to supervise SIFIs effectively; (ii) have the full suite of powers and political backing to intervene at an early stage and require corrective actions; (iii) have well-developed supervisory approaches and techniques that reflect the complexity of the financial system and its firms; and (iv) be held to a higher set of standards in supervising SIFIs. These recommendations were endorsed by the G20 (FSB, 2010f); self-assessment and followup action by members and incorporation in the international standards will follow.

These recommendations explicitly acknowledge that SIFIs pose a unique set of challenges and seek to provide a framework for their supervision. While developing enhanced regulatory requirements for SIFIs will take time, the final result of stronger supervisory requirements provides some comfort that excessive risk taking will be addressed. The recommendations recognize the importance of proactive supervision and that adjustment of some SIFIs' business strategies to tighter regulation may increase systemic risk. As a result, it is crucial to improve coordination and cooperation among supervisory agencies in the oversight of the most systemically important firms. The establishment of supervisory colleges for the large complex financial groups and the FSB peer review process to assess effectiveness and consistency of national measures will both make important contributions. 
Enhancing supervisory oversight and effectiveness will require strong political backing. Resources will be required to understand firms' business models, and political support will be required to back supervisors who seek to preemptively limit risky activities in what appear to be highly successful SIFIs. This problem is further compounded when a SIFI is owned by the state. Providing the necessary budget and staffing resources and authority to impose additional requirements on institutions (reporting) could prove challenging in a budget-constrained and low-growth environment. Supervisory efforts to strengthen governance, internal controls, and risk management capacity of banking groups will be essential. Also important will be aligning managers' incentives with those of the shareholders and regulators, including through compensation polices along the lines proposed by FSB, so that financial firms align these policies with prudent risk taking and that these policies are subjected to effective supervisory oversight and engagement by stakeholder (FSB, 2010a, and FSF, 2009). While this is, first and foremost, the responsibility of the industry, supervisory measures should also be taken to promote effective implementation in order to limit the firms' incentives to game the system.

\section{Enhanced transparency and disclosure}

Leveraging market discipline to motivate prudent management is a critical component of an effective financial infrastructure. Transparency and disclosure are needed if market discipline is to be effective (Pillar 3 of Basel II), and they act as natural restraints on excessive risk taking. Disclosure of timely and accurate data on individual firms' financial condition and exposures vis-à-vis other financial institutions and instruments helps creditors, counterparties, and shareholders better assess and identify systemic risks. By contrast, a lack of transparency and limited disclosure of the types and locations of risks prior to the crisis undermined the ability of markets and supervisors to assess firms' exposure. It also meant that, as problems arose, markets were unable to distinguish between healthy institutions and those that had taken on excessive amounts of high-risk assets and exposure. This lack of information exacerbated spillovers and led to the propagation of shocks within and across borders. It is critical that such transparency occur on a routine basis - waiting until a crisis to make such disclosures risks undermining market confidence in individual firms.

Significant progress is required to close data gaps. Most information needed to identify the buildup of systemic risks remains unavailable to the market, and large data gaps stemming from varying frequency and content of information across individual institutions hinder effective analysis. The key gaps include disclosure by SIFIs of their sectoral, market, and crossborder exposure; disclosure of off-balance-sheet items and complex structured products; the extent of interconnectedness across institutions; financial stability indicators; and transparency in OTC derivative markets (Johnston and others, 2009). This information may not be available even to supervisors in some countries, or if available, may not be made public. The BIS, FSB, and the Fund are working to identify and fill these information gaps. Agreement has been reached on a data template for global SIFIs, which contain information on the structure, exposures, and interconnectedness of their activities, and should be extended to all SIFIs.

\section{An effective and credible resolution framework to enhance resolvability}

Making orderly resolutions feasible without systemic disruptions, without generating moral hazard, and without exposing taxpayers to losses is one of the most critical 
elements of addressing the TITF problem. Severe problems in individual SIFIs, while hopefully infrequent, are inevitable, regardless of the quality of supervision and regulation. A system in which nonviable SIFIs can be taken over, management changed, shareholders wiped out, and unsecured creditors absorb losses, while at the same time forestalling threats to the financial system, would increase market discipline and reduce the moral hazard risk posed by SIFIs. Establishing that no institution is too important to fail or to cause losses to its creditors would level the playing field and should limit the ability of high-risk SIFIs to gain access to cheaper funding and to grow. Improving authorities' ability to maintain continuity of any vital economic functions makes the resolution of such institutions more feasible and credible.

To make SIFI resolution a viable option, recommendations proposed by the FSB in coordination with other international organizations, including the Fund, have focused on three key areas:

- $\quad$ Effective resolution regimes and tools - legal reforms, a resolution authority with powers tailored to the specific nature of the institutions' business activities, and restructuring mechanisms to allow recapitalization of an institution as a going concern;

- $\quad$ Effective cross-border coordination mechanisms between relevant home-host authorities; and

- $\quad$ Sustained recovery and resolution planning, made mandatory for G-SIFIs to improve their resolvability.

On resolution regimes, some progress has been made at the national level. The U.S. DoddFrank Act, for example, introduced an "Orderly Liquidation Authority" that allows the FDIC to apply a new regime for liquidating systemic financial companies (bank holding companies, nonbank financial companies, and any company predominantly engaged in financial activities). In Europe, new resolution regimes for bank and nonbank SIFIs have been introduced in a number of countries (including Belgium, Germany, Sweden, Switzerland, and the United Kingdom). The EC has made preliminary proposals including recovery and resolution plans (RRPs), powers to take early action, and resolution tools to take over a failing bank and transfer parts of its business to a bridge bank (EC, 2010). Following the consultations on this framework, a formal legislative proposal will be developed and its impact assessed (EC, 2011).

Much less progress has been made at the cross-border level. Most existing arrangements do not permit orderly cross-border resolutions. Operational and legal impediments to cross-border resolution regimes derive from differences in national resolution frameworks, the absence of mutual recognition and agreements for joining up home and host regimes, the absence of homehost burden-sharing arrangements, and a lack of planning for handling stress and resolution (FSB, 2010f). ${ }^{11}$ The complexity and integrated nature of group structures and operations, with multiple legal entities spanning national borders and business lines, also hinder rapid and orderly resolutions under current regimes.

\footnotetext{
${ }^{11}$ These include booking practices, the use of intra-group guarantees, global payments operations, information systems, and complexity in the structure of cross-border financial institutions, particularly the use of multiple legal entities in executing transactions and conducting business.
} 
To support the improvement of cross-border coordination, the Fund proposed in June 2010 an intermediate option to reach global solutions for cross-border resolution regimes. It recognized the need for significant political will to surrender national sovereignty to an international treaty and efficiency costs implied by some nationalistic approaches (IMF, 2010d). It called for amending national laws to remove existing legal impediments to international cooperation, allowing only countries that satisfy core coordination standards to participate in the framework. These standards establish principles for burden-sharing between cooperating authorities where resolution requires temporary public funds and contributions from deposit guarantee/resolution funds and for agreeing on legal and operating procedures to facilitate the cross-border effects of national resolution actions. ${ }^{12}$ Further work is under way to operationalize this framework.

Regarding the third key area-effective resolution planning-living wills have been proposed to encourage better advanced planning and to require preparation of a plan for each G-SIFI that demonstrates it can be resolved in an orderly fashion. The objective, as discussed by the FSB, is for firms and regulators to jointly develop systematic and holistic resolution and recovery plans (RRPs) to facilitate recovery and orderly wind-downs of SIFIs in the event of failure. These RRPs include (i) a recovery plan developed by the firm (and vetted by the supervisory authority) that identifies, and ensures that it can readily implement a range of recovery options in response to a shock; and (ii) an accompanying resolution plan developed by national authorities which ensures that the authorities understand firms' legal and operating structures and their economic functions, to determine whether and how national resolution tools could be used to resolve the firm at minimum systemic and public sector risk (see, for example, U.K. FSA, 2009).

RRPs are an important step forward and can make a valuable contribution to effective resolution frameworks for SIFIs. Such plans can promote better preparedness by individual firms for contingencies and by authorities for effective resolution. They provide essential information on a firm's assets and liabilities, commitments, exposure, and legal and operational structure. They should be useful in informing authorities about the type of reforms needed to strengthen their supervisory and resolution powers and tools and in identifying actions to address institutions that are too complex to resolve.

Resolution plans may face implementation challenges. In particular, developing effective resolution plans may prove difficult because of the complexity of some cross-border firms. Implementation challenges may also arise in a real case of distress, given the importance of institutions' retaining market confidence in their financial strength. Divestment of a key business line or other substantive recovery measure may be perceived as a sign of distress and trigger destabilizing reactions on the part of creditors. In this context, the RRP process highlights the need for effective cross-border arrangements for cooperation, information sharing, and decision-making when dealing with a failing institution. Further work needs to be

\footnotetext{
${ }^{12}$ Core coordination standards would consist of: measures to harmonize resolution laws, rescind national legislation that discriminate against overseas creditors, develop effective resolution tools and creditor safeguards, strengthen regulatory cooperation, and enhance the effectiveness and capacity of regulatory authorities.
} 
done to produce methodologies and criteria to assess institutions' resolvability and the consistent implementation of RRPs across different jurisdictions.

\title{
Effective burden-sharing with the private sector
}

\begin{abstract}
The use of "bail-inable" debt or "bail-in statutory powers" could play an important role in enhancing market discipline as part of an orderly resolution. The idea behind these instruments is to provide additional loss-absorbing capacity by converting private debt into equity capital when a bank comes under severe stress. Ensuring that private creditors provide loss-absorbing capital will boost market discipline and reduce the likelihood that taxpayer funds will be needed. The bail-in power (Box 1), a statutory approach to debt write-down or debt-to-equity conversion, deals directly with resolution of SIFIs and may provide resolution authorities with an additional resolution tool to restructure bank debt.
\end{abstract}

\section{Box 1. Bail-inable Debt Proposals}

Proposals for bail-inable debt, as well as for contingent capital, are under consideration as a potential market-based tool to address moral hazard risks associated with SIFIs. Regulators in several countries (Canada, the United States, and others in Europe) have shown interest in adding bail-in instruments to their crisis-management toolkits. The concept, the scope, and the precise role of bail-in are currently under discussion within the Basel Committee, FSB, and EU. ${ }^{1}$ An objective is to incentivize institutions to raise capital or to restructure debt voluntarily before a triggering of the bail-in power.

In general, the bail-in proposals are expected to provide a statutory approach to debt write-downs and debt-equity conversion, providing authorities with a new power to add to the capital base of a failing institution. By virtue of regulatory intervention while a distressed institution is operating under official administration (that is, conservatorship), supervisors can hold off declaring the institution insolvent and possibly avoid placing the institution into liquidation. The bail-in proposals would preserve the traditional priority of claims present in a formal liquidation (that is, equity holders absorb the first loss, followed by subordinated debt holders, followed by unsecured debt holders) with the prospect that, according to this priority, debt holders will obtain an equity interest. The prospect of such conversion rules on debt may add to market discipline and thus may also help curb excessive risk-taking.

For bail-in to be an effective resolution tool, it must be designed to overcome legal challenges and difficulties in crossborder implementation while mitigating potential systemic risks. The legal framework for statutory bail-in must be carefully elaborated to reduce legal uncertainty, because upon the occurrence of the trigger event, creditors would be forced to give up full legal claims in exchange for overall value maximization in order that business operations can continue normally. This could conflict with laws that guarantee property rights if applied retroactively or without explicit terms and conditions built into the investment that explicitly recognizes the right of authorities for debt write-off or conversion into equity at the point of nonviability. The effectiveness of statutory bail-in also will depend crucially on its recognition within all relevant jurisdictions. Coordination at an international level is important to preserve a level playing field and avoid unintended consequences for the functioning of bank debt markets. In principal, deposits, secured claims, and qualified financial contracts should be excluded from the scope of debt subject to bail-in.

${ }^{1}$ The Basel Committee issued minimum requirements on January 13, 2011, to ensure that all classes of capital instruments fully absorb losses at the point of nonviability before taxpayers are exposed to loss.

While potentially a useful resolution tool, careful consideration must be given to the design of bail-in power to mitigate or avoid financial stability risks. Such debt instruments should be accompanied by strengthened supervision, an enhanced capital base, improved disclosure, and an effective resolution regime - and should not be considered a stand-alone tool. A triggering of bail-in power could send negative market signals and destabilize markets during times of high market volatility and uncertainty. The marketability of the instruments subject to bail-in power is also uncertain given the potential discretionary element and 
investors' lack of familiarity with these instruments. Careful monitoring by supervisory authorities of the implied transfer of risks within the financial system and the potential buildup of systemic risks will be important. There may also be a case for restricting some holders of convertible instruments to limit the contagion effects across SIFIs (Pazarbasioglu and others, 2011). Ensuring consistency, transparency, and standardization will also be important to avoid complex structures and support cross-border crisis management.

\section{Conclusions And Policy Implications}

No private financial institution should be viewed by markets as being too important to be allowed to fail. SIFIs have demonstrated great capacity to propagate distress and undermine the normal functioning of the broader financial system and the economy given their scale, complexity, and interconnectedness. The implicit government backing they have enjoyed has provided them with funding and competitive advantage over non-SIFIs. The moral hazard they pose has been reinforced by the large-scale public support these institutions received during the recent crisis. Yet, despite the widely shared concern regarding the risks posed by these institutions, some have become even larger and more complex, worsening the associated moral hazard risk and the challenge of properly managing and supervising them.

Policies are therefore needed to address the systemic risk posed by institutions perceived as TITF and to reinstate market discipline. Efforts to address the TITF problem should aim to internalize the risks taken by these institutions and limit the negative externalities imposed on others. This could consist of the following mutually reinforcing elements:

- $\quad$ Materially more stringent capital requirements (and possibly liquidity requirements as appropriate methodologies are developed), designed to reduce the probability of failure and to limit systemic risk contributions;

- $\quad$ Intensive and proactive supervision commensurate with their complexity and risks;

- $\quad$ Enhanced transparency and disclosure requirements for early identification of risks; and

- $\quad$ Effective resolution regimes at the national and global level to make their resolution a credible, feasible, and viable option in the event of nonviability.

These policies should be accompanied by the following four elements to reinforce their effectiveness and limit their unintended consequences. First, there should be better policing of the firewalls and links between regulated and unregulated sectors and enhanced disclosure requirements for the nonbank sector to limit the possibility that banks indirectly retain the risk and that, if the risks are shifted away from banks, the result is not simply the relocation of systemic risk to entities not subject to monitoring or regulatory oversight. Second, it is essential to improve the understanding of the shadow banking system to prevent unregulated nonbank institutions from gaining systemic importance. Third, effective cross-border arrangements for cooperation, information-sharing, and funding are necessary to facilitate cross-border resolution and limit regulatory arbitrage in the absence of a harmonization of measures targeted at SIFIs. Finally, management incentives must be realigned to match those of the banking 
group and the regulators (for example, through effective compensation policies linked to better and sound performance) to limit the incentives for excessive risk-taking.

Although clear progress has been made in some of these areas, tangible results are needed on a number of issues, including: finalizing the methodology (and scope of application) to identify SIFIs; determining the level, composition, and coverage of a capital surcharge; institutionalizing international standards and translating the recommendations for intensive supervision of SIFIs into national practices; addressing data gaps; agreeing on cross-border resolution arrangements; and making visible progress in reforming compensation policies to align compensation structures in major financial institutions with prudent risk-taking, along the lines recommended by the FSB.

These complex issues have been under intensive discussion for many months within international forums, and they involve difficult policy judgments. The Fund too is contributing to these discussions and is enhancing its toolkit to incorporate the emerging recommendations into its surveillance framework. There is a risk, however, that it may take several years after agreement is reached to implement the essential elements of the TITF solution at the national and global level. At the same time, SIFIs continue to grow and may be reassuming some of their risky practices. There is also a risk of growing pressures at the national level to take immediate actions to limit the risk posed by SIFIs. As national legislation is approved, reaching a consensus at the international level may be even more difficult.

In the interim, a subset of the measures that are simple and straightforward could be implemented internationally on a consistent basis. These would include an announcement that SIFIs identified as TITF will be required to hold significantly more high-quality (lossabsorbing) capital than systemically less important institutions (as already proposed in a few jurisdictions), combined with actions to accelerate adoption of the FSB recommendations for enhanced supervision to reduce the risk that tighter requirements simply relocate systemic risk to affiliates subject to less or no regulation. Basel capital requirements are minimum standards but incorporate the expectation that banks hold higher capital for idiosyncratic and system-wide risks. While the current proposals will raise the minimum requirements further, SIFIs identified as TITF should have higher equity capital requirements than required by Basel III of all banks as more progress is made in reaching agreement on other components of the TITF solution, such as effective national and cross-border resolution regimes. ${ }^{13}$ There should be a reasonable transition period during which undercapitalized banks can build their capital bases to limit the risks to the real sector from any reduced availability of credit. Higher capital requirements, combined with enhanced supervision, would have the teeth required to bite into the propensity of SIFIs to continue to accumulate systemic risk. These actions should be applied across all major jurisdictions as the transition to the full implementation of the TITF framework is achieved.

\footnotetext{
${ }^{13}$ See, for example, Miles, Yang, and Marcheggiano (2011). Many G-SIFIs already hold significantly higher Tier 1 capital than the current Basel minimum.
} 


\section{APPENDiX I: Is Big BEAUTIFUl? EVIDENCE ON THE ECONOMIES OF SCALE/SCOPE AND DiversifiCATION BENEFITS OF FinANCIAL CONGLOMERATES}

On balance, empirical evidence provides mixed evidence for significant gains generated by large and diversified banks, making it difficult to conclude whether bigger is better.

- $\quad$ Proponents of the economies-of-scale argument note efficiencies in servicing large and global nonfinancial businesses, promoting local financial market development, and facilitating capital flows to emerging market economies. Recent empirical research finds economies of scale in the U.S. banking sector (Wheelock and Wilson, 2009). Integrated servicing of the needs of globally active nonfinancial firms is a key contribution of large banks. Cline (2010) points to the contribution of large global banks in integrating global stock, bond, and currency markets and in easing the cost of access to financial capital by emerging market firms.

- $\quad$ Others argue that larger banks can generate efficiency gains through economies of scale but only up to a certain size threshold. Empirical studies find that gains from economies of scale for banks peak at lower levels of total assets than the median size of most global banks:

- In their survey of literature covering most of the industrialized countries (Australia, Canada, Europe, Japan and Canada), Amel and others (2004) find that economies of scale are maximized for a total asset size of $\$ 10$ billion. Other studies estimate the maximum efficient size of commercial banks to be somewhere between $\$ 25$ and $\$ 100$ billion. The Bank for International Settlements (2010) concludes that there is scant evidence in the literature for the existence of scale/scope economies in international banking.

- Moreover, there is mixed evidence on whether, on average, mergers and acquisitions create significant efficiency gains or generate significant shareholder value. Results in early studies surveyed in Amel and others (2004) find no significant evidence on either front. More recent studies surveyed in DeYoung, Evanoff, and Molyneux (2009) suggest that there is some evidence that North American mergers can improve efficiency, although they may not create stockholder wealth, whereas in Europe, both efficiency gains and enhanced stockholder value can be achieved.

More diversified banks may generate higher risk-adjusted returns and hence have higher market values, although the empirical evidence is again mixed.

- $\quad$ Using a large sample of banks from 43 countries, van Laeven and Levine (2007) find that the market value of financial conglomerates that engage in multiple activities is lower compared with financial conglomerates that are broken into financial intermediaries that specialize in the individual activities. This suggests that either economies of scale/scope are not sufficiently large to produce a diversification premium or that diversification intensifies agency problems and destroys value. (Other potential 
sources of value destruction in a diversified conglomerate include inefficient crosssubsidization and opacity of the hybrid conglomerate model.)

- Using U.S. data, Schmid and Walter (2009) find that firms that combine commercial banking and insurance and those that combine commercial banking and investment banking show a significant diversification premium. For the very large firms, they find a substantial premium, pointing to the existence of too big to fail guarantees.

- $\quad$ A study by van Lelyveld and Knot (2009) that focuses specifically on the valuation of bank-insurance conglomerates in the EU finds no universal diversification discount but rather significant variability. They also find that the discount is explained by size (increasing), familiarity with the conglomerate business model (decreasing), and the risk profile (decreasing).

- $\quad$ Stiroh and Rumble (2006) find that gains from diversification are offset by increased risk from volatile income-generating activities such as trading. 


\section{APPENDIX II: SAMPLE DESCRIPTION}

- $\quad$ Regional coverage: The sample includes 84 banks from Europe, Asia, Brazil, Canada, and the United States that are deemed to be nationally, regionally, or globally systemically important given their size or interconnectedness. The data panel covers 2000 to 2009 and is not fully balanced due to some data gaps, particularly in earlier years, although the data gaps are not significant.

- Business model: The sample is partitioned into three groups - investment banks, commercial banks, and universal banks - based on quantitative criteria and qualitative judgment. The quantitative categorization of banks is based on the proportion of securities in the banks' total assets: banks are classified as investment banks if loans are less than 15 percent of total assets or securities are more than 60 percent of total assets, and as commercial banks if loans are more than 60 percent of total assets or securities are less than 15 percent of total assets. After these criteria are applied, all other banks are classified based on judgment, taking into account the scope of derivatives activities, the relative shares of securities and loans, and the share of trading income in total revenue (Figure 6). The final categorization is cross-checked against categorizations used by private sector analysts. ${ }^{14}$

- Cross-border activities: Banks are classified as domestic if they derive 100 percent of their 2009 revenue from domestic activities; as banks with significant international presence if they derive more than 40 percent of their revenues from international activities; and as banks with limited international presence if less than 40 percent of their revenues are derived from international activities (Figure 6).

Figure 6. Distribution of Banks by Business Model and Scale of Cross-Border Activity
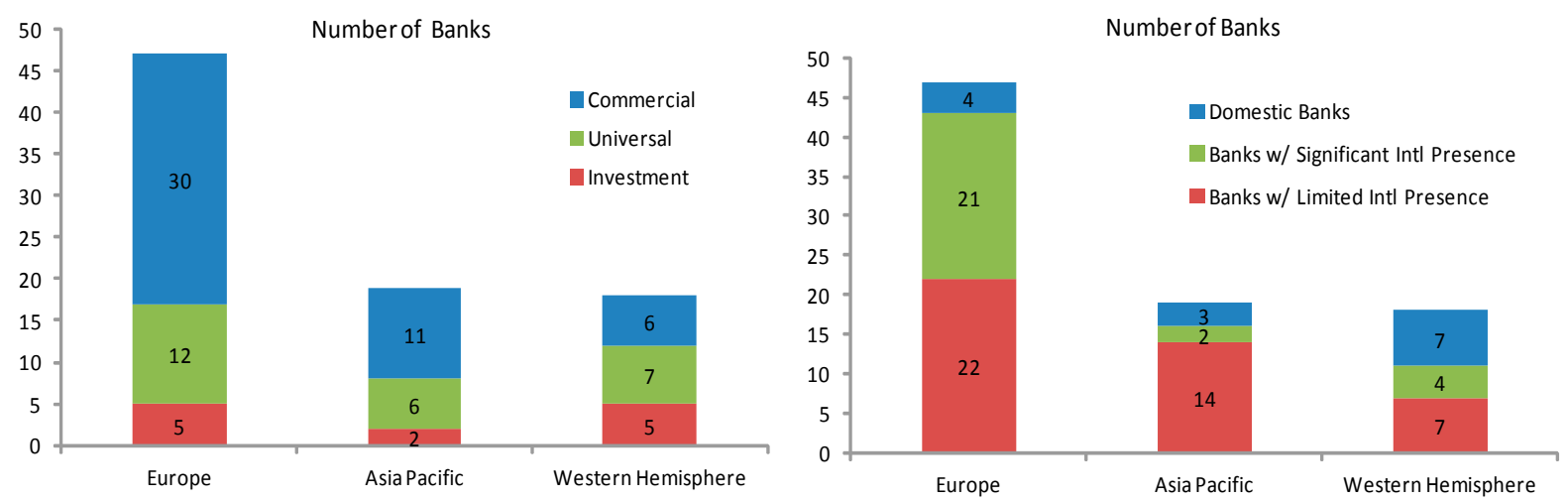

Sources: Bloomberg; World Economic Outlook database; Banks’ reports; and IMF staff calculations.

\footnotetext{
${ }^{14}$ Note that any categorization of banks by business model involves judgment. The investment bank category is the easiest to define, and there seems to be a consensus among analysts on which banks fall in this category. The boundaries between commercial and universal banks are more of a grey area.
} 
Size, interconnectedness, and substitutability: All banks in the sample are ranked by selected indicators of size, interconnectedness, and substitutability:

- $\quad$ Size is measured in two different ways: (i) absolute size, which is total assets in U.S. dollars, and relative size, which is total assets as a share of the home country's nominal GDP.

- Interconnectedness ranking is an average of three rankings: (i) securities holdings in U.S. dollars, ${ }^{15}$ (ii) wholesale funding in U.S. dollars, and (iii) the wholesale funding ratio.

- Substitutability ranking is an average of rankings in the global wholesale finance league tables, including: (i) for syndicated loans; (ii) for international bonds; and (iii) for equity.

This suggests that size alone does not capture all dimensions of the TITF problem. For example, of the 21 largest institutions by total assets, 14 could also be categorized as either the most interconnected or the least substitutable, and 11 have all three characteristics (Figure 7). Figure 8 provides further information on the distribution of the sample banks by size, interconnectedness, and substitutability.

Figure 7. Number of Banks in the Top Quartiles of the Distributions by Absolute Size, Interconnectedness, and Substitutability

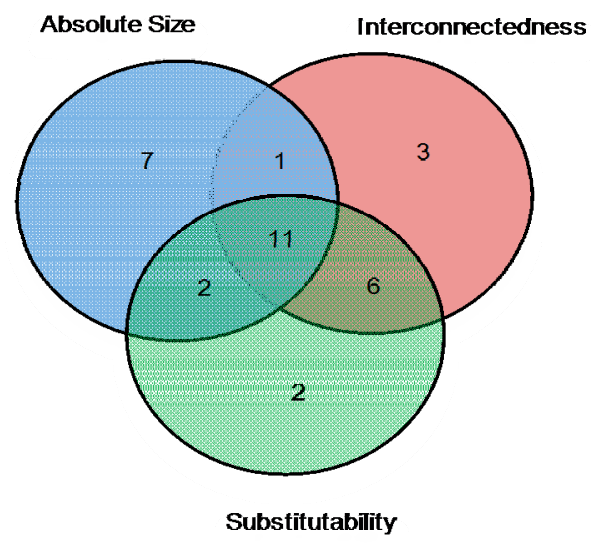

Source: IMF staff calculations.

\footnotetext{
${ }^{15}$ Securities holdings of a bank include marketable securities and other short-term investments (that is, liquid investments expected to convert to cash within a reasonably short period of time, usually less than one year). They include repos, reverse repos, and securities held by brokerage subsidiaries, as well as AFS and HTM securities classified as short-term. They exclude interest or dividends accrued on investments and pledged amounts and accounts on lien, but may include short-term interest-bearing loans to third parties if not disclosed separately.
} 
Figure 8. Distribution of Banks by Size and Interconnectedness Quartiles and by Business Model and Region

(Q1 is the top quartile; Q4 is the bottom quartile)

Distribution by absolute size (Total assets) and by business model

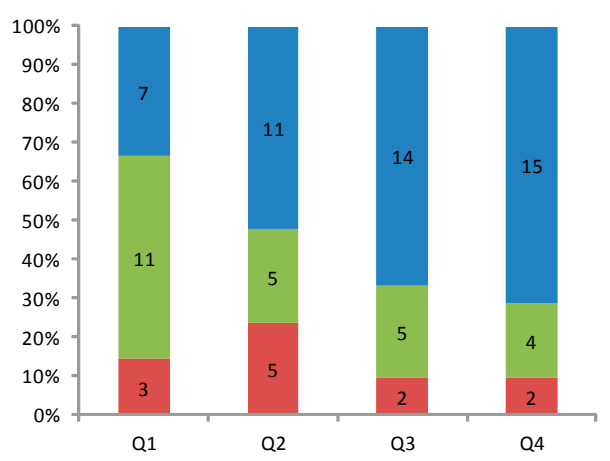

Distribution by relative size (Total assets/GDP) and by business model

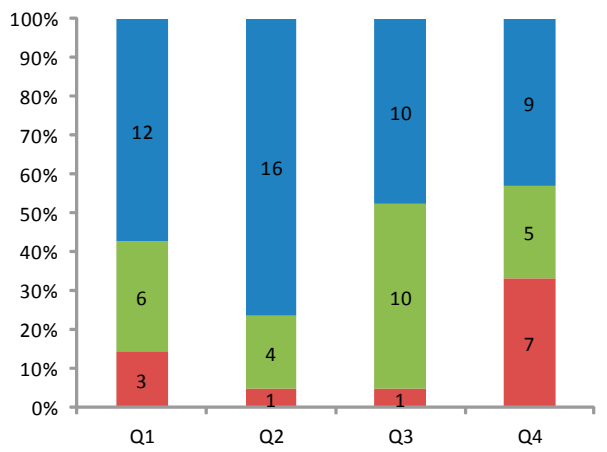

Distribution by interconnectedness and by business mode

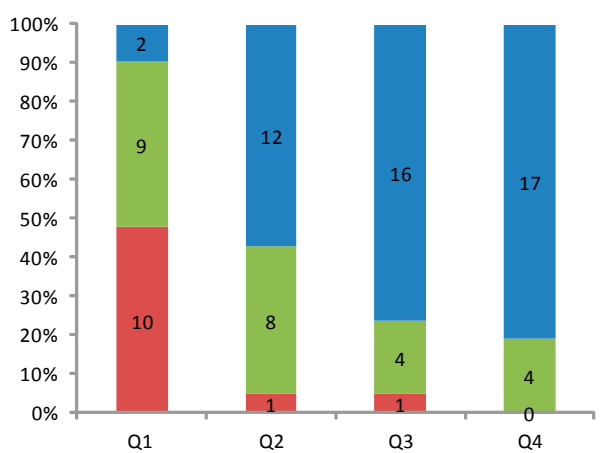

Distribution of by absolute size (Total assets) and by region

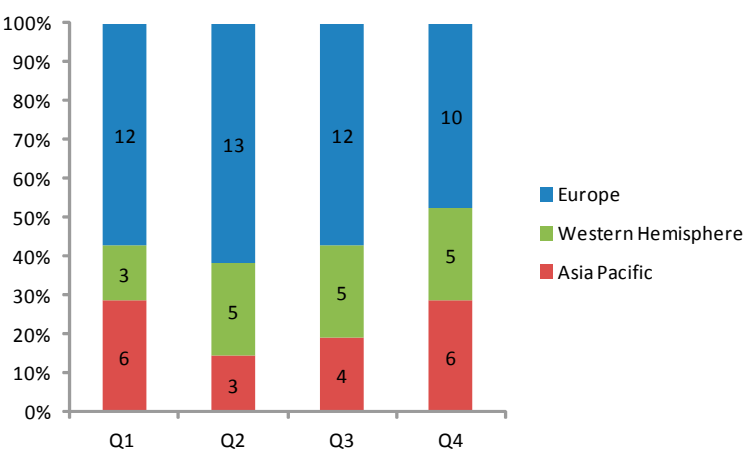

Distribution by relative size (Total assets/GDP) and by region
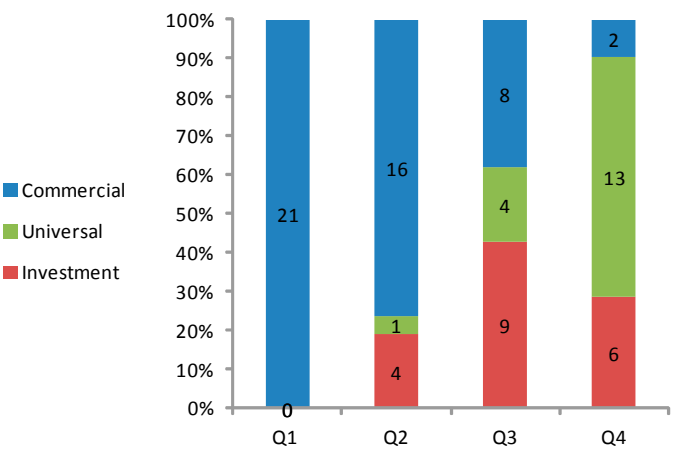

Europe

Western Hemisphere

- Asia Pacific

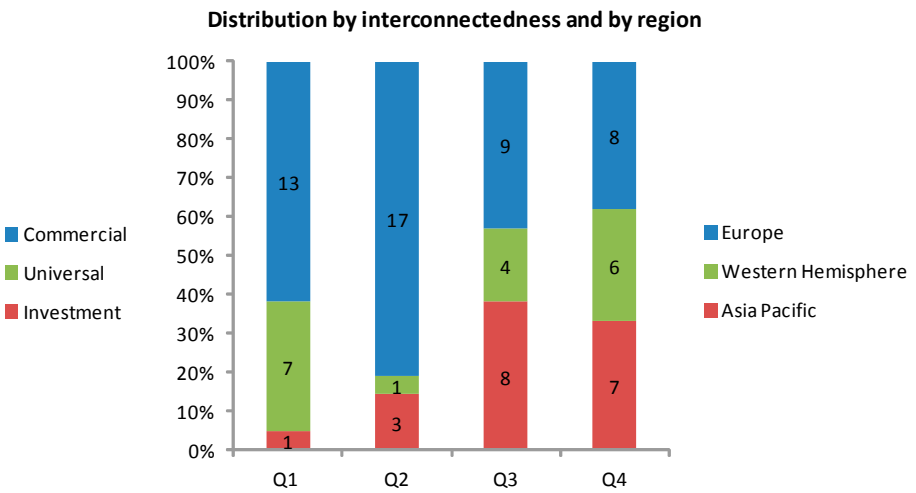

Sources: Bloomberg; World Economic Outlook database; Banks' reports; and IMF staff calculations. 


\section{REFERENCES}

Alessandri, P., and A.G. Haldane, 2009, "Banking on the State" (London: Bank of England). http://www.bankofengland.co.uk/publications/speeches/2009/speech409.pdf.

Amel D., C. Barnes, F. Panetta, and C. Salleo, 2004, "Consolidation and Efficiency in the Financial Sector: A Review of the International Evidence," Journal of Banking \& Finance, Vol. 28, pp. 2493-519.

Basel Committee on Bank Supervision (BCBS), 2009a, “Adjustments to the Basel II Market Risk Framework," press release (Basel: Bank for International Settlements, June 18). http://www.bis.org/press/p100618.htm.

,2009b, Revisions to the Basel II Market Risk Framework, Final Version (Basel: Bank for International Settlements, July). http://www.bis.org/publ/bcbs158.htm.

, 2009c, Strengthening the Resilience of the Banking Sector (Basel: Bank for International Settlements, December), http://www.bis.org/publ/bcbs164.htm.

,2010, "The Group of Governors and Heads of Supervision Reach Broad Agreement on Basel Committee Capital and Liquidity Reform Package," press release (Basel: Bank for International Settlements, July 26, 2010). http://www.bis.org/press/p100726.htm.

Bank for International Settlements (BIS), 2010, 80th Annual Report. (Basel, June).

Buffa di Perrero A., A. Ilyina, S. Iorgova, T. Kisinbay, and V. Tulin, 2011, “The Too-ImportantTo-Fail Problem: Some Stylized Facts,” IMF Working Paper (forthcoming; Washington: International Monetary Fund).

Cho, D., 2009, “Banks 'Too Big to Fail’ Have Grown Even Bigger,” Washington Post (August 28).

Chow, J., and J. Surti, 2011, "Restricting the Size and Scope of Activities of Systemically Important Financial Institutions," IMF Working Paper (forthcoming; Washington: International Monetary Fund).

Cline, W., 2010, Financial Globalization, Economic Growth, and the Crisis of 2007-09, Peterson Institute of International Economics (Washington).

Committee on the Global Financial System, 2010, "Long-Term Issues in International Banking," CGFS Papers No. 41 (Basel: Bank for International Settlements). http://www.bis.org/publ/cgfs41.pdf.

DeYoung, R., D. Evanoff, and P. Molyneux, 2009, "Mergers and Acquisitions of Financial Institutions: A Review of the Post-2000 Literature," Journal of Financial Services Research, Vol. 36, pp. 87-110.

European Commission (EC), 2010, An EU Framework for Crisis Management in the Financial Sector, COM(2010) 579 final (Brussels, October 20). http://ec.europa.eu/internal_market/bank/docs/crisismanagement/framework/com2010_579_en.pdf. 
,2011, "Technical Details of a possible EU Framework for Bank Recovery and Resolution,” DG Internal Market and Services Working Document (Brussels, January). http://ec.europa.eu/internal_market/consultations/docs/2011/crisis_management/consultation_ paper_en.pdf.

Fiechter, J., İ. Ötker-Robe, A. Ilyina, M. Hsu, A. Santos, and J. Surti, 2011, "Subsidiaries or Branches: Does One Size Fit All?" IMF Staff Discussion Note 11/4 (Washington: International Monetary Fund). www.imf.org/external/pubs/ft/sdn/2011/sdn1104.pdf.

Financial Stability Board (FSB), 2010a, "Financial Stability Board Meets in Seoul," press release (Basel: Bank for International Settlements, October 20). http://www.financialstabilityboard.org/press/pr_101020.pdf.

, 2010b, FSB Report on Progress Since the Washington Summit (Basel: Bank for International Settlements, November). http://www.financialstabilityboard.org/publications/r_101111b.htm.

, 2010c, "G20 Leaders Endorse FSB Policy Framework for Addressing Systemically Important Financial Institutions," press release (Basel: Bank for International Settlements, November 12). http://www.financialstabilityboard.org/press/pr_101111a.pdf.

,2010d, Intensity and Effectiveness of SIFI Supervision: Recommendations for Enhanced Supervision, prepared in consultation with the IMF (Basel: Bank for International Settlements, November 1). http://www.financialstabilityboard.org/publications/r_101101.pdf.

, 2010e, "Letter to G20 Leaders on Progress of Financial Regulatory Reforms," press release (Basel: Bank for International Settlements, November 9). http://www.financialstabilityboard.org/publications/r_101109.pdf.

, 2010f, Reducing the Moral Hazard Posed by Systemically Important Financial Institutions (Basel: Bank for International Settlements, November 11). http://www.financialstabilityboard.org/publications/r_101111a.pdf.

Financial Stability Forum (FSF), 2009, FSF Principles for Sound Compensation Practices (Basel: Bank for International Settlements, April 2). http://www.financialstabilityboard.org/publications/r_0904b.pdf.

Goodhart, C., 2010, "How Should We Regulate Bank Capital and Financial Products? What Role for 'Living Wills'?" in The Future of Finance and the Theory that Underpins It: The LSE Report, ed. By A. Turner, A. Haldane, P. Woolley, S. Wadhwani, C. Goodhart, A. Smithers, A. Large, J. Kay, M. Wolf, P. Boone, S. Johnson, and R. Layard (London: London School of Economics and Political Science).

Goldstein, M., and N. Véron, 2011, “Too Big to Fail: The Transatlantic Debate,” Working Paper Series 11-2. (Washington: Peterson Institute for International Economics). http://www.iie.com/publications/interstitial.cfm?ResearchID $=1745$.

Haldane, A., 2010, “The \$100 Billion Question," Speech to Institute of Regulation and Risk, Hong Kong (March 30). http://www.bankofengland.co.uk/publications/news/2010/036.htm. 
Herring, R., 2009, "Wind-Down Plans as an Alternative to Bailouts," Briefing Paper 15

(Washington: Pew Financial Reform Project).

http://www.pewfr.org/admin/project_reports/files/Wind-down-plans.pdf.

International Monetary Fund (IMF), 2010a, "A Fair and Substantial Contribution by the Financial Sector, Report to the G-20” (Washington, June).

http://www.imf.org/external/np/g20/pdf/062710b.pdf.

, 2010b, Global Financial Stability Report, April (Washington).

http://www.imf.org/external/pubs/ft/gfsr/2010/01/index.htm.

, 2010c, "Systemic Liquidity Risk: The Resilience of Institutions and Markets," Chapter 2 in Global Financial Stability Report, October. (Washington).

http://www.imf.org/external/pubs/ft/gfsr/2010/02/pdf/chap2.pdf.

, 2010d, "Resolution of Cross-Border Banks-A Proposed Framework for Enhanced

Coordination” (Washington). http://www.imf.org/external/np/pp/eng/2010/061110.pdf.

, 2011, Global Financial Stability Report, April (Washington).

http://www.imf.org/external/pubs/ft/gfsr/2011/01/index.htm.

IMF/BIS/FSB, 2009, "Guidance to Assess the Systemic Importance of Financial Institutions, Markets, and Instruments: Initial Consideration, Report with the Bank for International Settlements to the G-20," Report to the G-20 Finance Ministers and Central Bank Governors by the Staff of the International Monetary Fund and the Bank for International Settlements, and the Secretariat of the Financial Stability Board (Washington and Basel: International Monetary Fund, Bank for International Settlements, and Financial Stability Board, October), http://www.imf.org/external/np/g20/pdf/100109.pdf.

IMF/BIS/FSB, 2010, "Capital and Liquidity Surcharges and Financial Levies and Taxes: Coherence and Consistency: A Note by the FSB, IMF, and BCBS" (Washington and Basel: International Monetary Fund, Bank for International Settlements, and Financial Stability Board, April 18).

Johnson, S., and J. Kwak, 2010, 13 Bankers: The Wall Street Takeover and the Next Financial Meltdown (New York: Random House).

Johnston, R. B., E. Psalida, P. de Imus, J. Gobat, M. Goswami, C. Mulder, and F. Vazquez, 2009, "Addressing Information Gaps," IMF Staff Position Note 09/06 (Washington: International Monetary Fund, March).

Laeven, L., and R. Levine,2007, "Is There a Diversification Discount in Financial Conglomerates?" Journal of Financial Economics, Vol. 85, pp. 331-67.

Mengle, D., 2010, “Concentration of OTC Derivatives among Major Dealers," ISDA Research Notes, Issue 4. www2.isda.org/attachment/MTY3OA==/ConcentrationRN_4-10.pdf.

Miles, D., J. Yang, and G. Marcheggiano, 2011, “Optimal Bank Capital,” Discussion Paper 31 (London: Bank of England, External MPC Unit, January). 
Shecter, B., 2011, "Post-Crisis, Bank Risk on Rise Again Financial Post," Calgary Herald (March 29), http://www.calgaryherald.com/story print.html?id=4517378\&sponsor=curriebarracks.

Ötker-Robe, İ., C. Pazarbasioglu, and others, 2010, "Impact of Regulatory Reforms on Large Complex Financial Institutions," IMF Staff Position Note 10/16 (Washington: International Monetary Fund). http://www.imf.org/external/pubs/cat/longres.aspx?sk=24314.0.

Pazarbasioglu, C., J. Zhou, V. Le Leslé, and M. Moore, 2011, "Contingent Capital: Economic Rational and Design Features,” IMF Staff Discussion Note 11/01 (Washington: International Monetary Fund, January). imf.org/external/pubs/ft/sdn/2011/sdn1101.pdf.

Schmid, M. M., and I. Walter, 2009, "Do Financial Conglomerates Create or Destroy Economic Value?" Journal of Financial Intermediation, Vol. 18, pp. 193-216.

Senior Supervisors Group, 2008, "Observations on Risk Management Practices during the Recent Market Turbulence” (New York: Federal Reserve Bank of New York, March). , 2010, "Risk Management Lessons from the Global Banking Crisis of 2008" (New York: Federal Reserve Bank of New York, October).

Stiroh, K.J., and A. Rumble, 2006, "The Dark Side of Diversification: The Case of U.S. Financial Holding Companies," Journal of Banking and Finance, Vol. 30, pp. 2131-161.

Tarullo, D., 2009, “Confronting Too Big to Fail,” Speech at the Exchequer Club, Washington, D.C. (Washington: Board of Governors of the Federal Reserve System, October 21). http://www.federalreserve.gov/newsevents/speech/tarullo20091021a.htm.

U.K. Financial Services Authority (FSA), 2009, The Turner Review: A Regulatory Response to the Global Banking Crisis. (London, March). www.fsa.gov.uk/pubs/other/turner_review.pdf.

van Lelyveld, I., and K. Knot, 2009, "Do Financial Conglomerates Create or Destroy Value? Evidence for the EU," Journal of Banking and Finance, Vol. 33, pp. 2312-321.

Viñals, J., 2009, “Too Important to Fail?” iMFdirect (December 8). http://blogimfdirect.imf.org/2009/12/08/too-important-to-fail/.

Viñals, J., J. Fiechter, C. Pazarbasioglu, L. Kodres, A. Narain, and M. Moretti, 2010, "Shaping the New Financial System," IMF Staff Position Note 10/15 (Washington: International Monetary Fund). http://www.imf.org/external/pubs/cat/longres.aspx?sk=24204.0.

Viñals, J., J. Fiechter, and others, 2010, "The Making of Good Supervision: Learning to Say No," IMF Staff Position Note 10/08 (Washington: International Monetary Fund). www.imf.org/external/pubs/ft/spn/2010/spn1008.pdf.

Wheelock, D. and P. Wilson, 2009, “Are U.S. Banks Too Large?," Federal Reserve Bank of St. Louis Working Paper 2009-054B, (St. Louis: December). 